\title{
Macroeconomic Determinants of Households' Credit Risk: Empiric Evidences from Macedonia
}

\author{
Lindita Muaremi \\ PhD candidate; Lecturer, Faculty of Economics, University of Tetova, FYROM \\ Email: lindita.muaremi@unite.edu.mk \\ Prof.Dr. Drini Salko \\ Lecturer of Finance; Agricultural University of Tirana \\ Email: dsalko@ubt.edu.al
}

\section{Doi:10.5901/ajis.2016.v5n3s1p351}

Abstract

\begin{abstract}
In general, the credit risk is considered as more problematic risk for the banking system. Credit given by banks is divided into loans for business and loans to individuals. The effects of the financial and debt crisis are also felt in Macedonia. This is especially noticeable after 2010, from the growth of non-performing loans against total loans granted. The non-performing individuals' loan is a measure of credit risk of individuals. It is of particular interest to investigate the factors that determine the behavior of non-performing loans to individuals. This study sheds light on the effects that macroeconomic factors have on the credit risk of individuals. The analysis of time series and the rigorous application of the econometric model challenged the strong and significant connection of the risk free interest rate, the index of house prices, the exchange rate and economic growth of the credit risk of individuals. All these factors have a positive relationship with this risk, with the exception of economic growth. It is more than logical that an improvement of economic growth will lower the credit risk of the individual, because the rate of non-performing loans to individuals will decrease. Economic growth means an increase in the opportunities to pay back the loan. Policies with focus on economic growth, could lead to a softening of the credit risk of individuals.
\end{abstract}

Keywords: Economic growth, credit risk, interest rate; currency

\section{Introduction}

Credit risk arises from the fact that it provided a lot of money and this money is expected to turn and after a certain time to return the interest. If this money is not partially or fully back, then the risk of not returning money to materialize, so it happened. As understood, there is an agent that requires funding of its projects to achieve a result and in turn found another agent that is able to support his project through grant money.

There is an agreement or consensus in theory regarding the determination of credit risk as one of the most important for economic societies dealing with finances (Blaschke, Matthew, Majnoni, \& Peria, 2001; Worrell, 2004; Rinaldi \& Sanchis-Arellano 2006; Kalluci \& Hill, 2010; BAriSiTz, 2011). All provide arguments in favor of this statement.

The literature on credit risk is wide, but in recent years it has consolidated many, with other financial problems. Part of the consolidation of this theory is undoubtedly the behavior of evidence to substantiate the claimed theoretical connections.

The need to investigate more on the 2007-2008 financial crisis, has led many authors to explore the effects emanating from the financial system. Part of this investigation can not even be credit risk. There are researchers who have seen the connection of credit risk to economic growth, as there are others who see the risk factors in view of the financial sector.

It is difficult to find any serious study that addresses credit risk of the banking system and do not integrate into the analysis of factors outside the financial system. This means that everyone agrees that credit risk is determined by many factors, which not only belong banking system.

The following will be a review of the literature on credit risk, with the aim to clarify the problem and to address it properly resolving it. Also, there is literature review underestimated in terms of the method used to investigate the importance of factors that determine credit risk. 


\section{Review on Method and Factors}

Above it was introduced ways of measuring risk. We should stop and have a discussion on this point. Measurement of the above risk refers to the case of an entity, while in this paper is about risk in a macroeconomic context. So there are two different situations: the first within an entity, while the second in the context of many entities. The following will summarize the literature on the method of measuring credit risk.

Worrell (2004) is a researcher who has made a review in a paper to the FMN on the methods used to assess the effects of the financial sector, making even suggested an integrated approach. With this article he suggests a strategic approach to use quantitative techniques available to measure the impact of the financial sector.

The method used to track the effects of macroeconomic indicators in the credit risk is what used Rinaldi and Sanchis-Arellano (2006) and especially Kalirai and Scheicher (2002) in their study modeling of macroeconomic variables that have an effect on risk credit also made certain changes that reflect the characteristics of the economy of the former Yugoslav Republic of Macedonia. In this study would not have taken into account the specific features of borrowers, but will assume the credit risk of banks is threatening our environment associated with macroeconomic consider, which includes banks with the borrowers. Interest at this point is the identification of these macroeconomic factors that may affect the growth of problem loans.

Blaschke et al. (2001), in an article discussing the International Monetary Fund, propose a method for measuring credit risk through non-performing loans ratio to total assets. This report is the first to feature several macroeconomic factors such as interest rates, inflation and real growth rate of GDP or changes in foreign trade. Specifically, the proposed model is:

$$
\left(\frac{N P L}{(\text { Active })_{i t}}=\alpha+\beta \cdot i_{i L}+\gamma \cdot p_{i t}+\delta \cdot \Delta G D P_{i t}+\lambda \cdot \Delta T o T_{i t}+\varepsilon_{i t}\right.
$$

Where the NPL means loans expressed in monetary value, monetary value assets refer to assets, is the nominal interest rate, the percentage change in real GDP and the change in percentage of foreign trade. Such an approach has the advantage of dynamic analysis that are suitable for assessing the effects of short-term as well as long-term effects, such as using an error correction model (ECM, error correction model).

$$
\triangle L L P=\alpha_{0}+\alpha_{1} x_{1 t}+\ldots+\alpha_{i} x_{i t}+u_{t}
$$

Where LLP is the ratio of total loan loss provisions to total loans, xit represents the change in the i factor in the time $t$, and ut is the residual term which allegedly has average 0 and standard deviation $\sigma 2$.

Rinaldi and Sanchis-Arellano (2006), researcher at the European Central Bank recomend another method to measure credit risk. Their specification is:

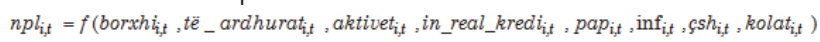

NPL is logarithmic transformation where the rate for individuals performing loans to total loans to individuals; debt is a variable that allegedly show the NPL, which is calculated as the ratio of total household debt (including mortgages, consumer loans and credit cards) to income available to consumers; revenues are available income of consumers and are logarithm model; assets is the ratio of financial assets held by a consumer with available revenues, where the model is logarithm; real credit is the real interest rate on the loan; pap is the unemployment rate; inf is the inflation rate. In the model they are covered by Rinaldi and Sanchis-Arellano (2006), two other variables very important. They are: CSH, the index of housing prices and Kola part collateral loans, loans that were then executed collateral.

Kalluci and Hill (2010), in a conference presentation on the Bank of Albania, have determined the factors that govern credit risk in Albania, making three distinctions: the credit to the economy as a whole, lending credit to businesses and households. The basis for the development of their presentation served submissions Blaschke et al. (2001), and Scheicher Kalirai (2002) and Rinaldi and Sanchis-Arellano (2006).

Considering the literature review, the level of problem loans is considered one of the best evaluators of credit risk (Kalluci \& Hill, 2010; Messai \& Jouini, 2013). There are also those authors for measuring this risk using credit loss provisions (Kalirai \& Scheicher, 2002).

\section{Expression of the Concepts in Variables}

One of the key steps in the search process considered the expression of concepts or variables operationalizing formulation scheme. It has to do with the definition of a concept and its measurement by a variable, and link concepts with each other. It means the transfer of concepts from the world of theory and observation in the world, the world of observation. It also provides information on concepts for a cause and consequence of the phenomenon under study 
(Skreli \& Cera, 2013). In general, preferably made as such schemes, so that hypotheses are formulated and expect to be checked with a certain method.

In the case of theory and logic are confident level which is the causative factor and what the consequence factor. But this submission are not confident to say even in the case of this dissertation. Precisely for this we need figures and econometric models.

Operationalization scheme may appear in the form of a table. Given in the first column taken from the theory concepts, which conducts analyzes the abstract concept and its connection or relationship with other concepts. To do this, the literature review helps the field of study and analysis of the applicant based on his experience, or experience (Skreli \& Cera, 2013). When talking about the connection between concepts refer logical connection between them, which leads in the direction of causality between concepts and direction of the connection.

The direction of causality factors shapes the causes and factors that undergo a variation corresponding to the change factor because, while the direction of the connection has to do with the relationship between the positive and negative factors. The second column refers to the world of observation or variables, which means how is passed from the world of theoretical concepts to the world of observation. This is one of the most delicate transitions in searches for the exact not measure concepts can lead to deformities research fair and deviations from reality. If the world of theory and concepts talk about cause and effect factors in the world of observation it is preferable to talk with language dependent variables and independent. Referring to the scheme, we will notice a column titled "Position regression", where each row is marked for "Dependent" or "Independent", corresponding to factor dependent and independent factors, consequences and causes. The third column is the symbol of the relevant concept. This symbol is used for cuts in the analysis of data as well as regressions to control hypotheses. Here it is preferred that the variables be explained in terms of the measurement method. Besides these, the scheme is well established position of each variable in the regression and the expected signs of connectivity the independent variable with the addicts.

\subsection{The link between credit risk and macroeconomic factors and assumptions}

We propose many scholars (Blaschke et al., 2001; Kalluci \& Hill, 2010; Messai \& Jouini, 2013), as the dependent variable in this relationship is taken non-performing loans (kr_prob), while the independent variables are the norm bill treasury 3mujore (bth3); M2 monetary aggregate, the housing price index (ind_sh); the growth rate of exports (eks_eur); real exchange rate (k_këmb) and economic growth (GDP).

\begin{tabular}{|c|c|c|c|c|c|}
\hline Concept & Variable & Symbol & Measure & Position regression & Sign expected \\
\hline Credit risk & Credit with risk & kr_prob & Percent & \multicolumn{2}{|c|}{ Dependent } \\
\hline $\begin{array}{l}\text { no risk interest } \\
\text { rate }\end{array}$ & Rate of bones & bth3 & Percent & Independent & + \\
\hline $\begin{array}{l}\text { Aggregate } \\
\text { monetary }\end{array}$ & $\begin{array}{l}\text { Aggregate monetary } \\
\text { M2 }\end{array}$ & M2 & Value dinar & Independent & - \\
\hline Real state & Index of real state & ind_sh & & Independent & - \\
\hline Export & Growth of export & eks_eur & Log export & Independent & - \\
\hline Exchange rate & $\begin{array}{l}\text { Exchange rate in } \\
\text { dinar me dollar in us } \\
\text { and euro }\end{array}$ & k_këmb & $\begin{array}{l}\text { USD/MAD } \\
\text { EUR/MAD }\end{array}$ & Independent & $-1+$ \\
\hline Economic growth & $\begin{array}{l}\text { Gross domestic } \\
\text { product }\end{array}$ & GDP & Value dinar & Independent & - \\
\hline
\end{tabular}

Analysis is included in the interest rate of treasury bills, because it serves as the basis for banks when they set lending interest rates over. Another important effect is the growth rate of the monetary aggregate $\mathrm{M} 2$, which for every increase of $1 \%$ predicted decreases loans. The real exchange rate has a positive correlation with loans, so any devaluation of the currency by $1 \%$, loans are expected to grow. Exports are measured by the difference log exports, which mean an increase in exports. Export growth is expected to be accompanied by a decline of credit risk, as would be expected inflows from trade. With regard to prices, a price index increased by $1 \%$ expected to reduce loans.

In this dissertation it is not only appreciated the connection between the rate loans and macroeconomic indicators, but also evaluate the connection of these macro-variables and solvency of two main categories: businesses and individuals. Each category is represented by an econometric model in order to become more understandable relationship between dependent variables and independent ones. 
At this point, in accordance with Blaschke et al. (2001), Kalluci and Hill (2010) and the Messai and Jouini (2013), can be formulated these hypotheses:

- If you increase risk-free interest rate, the credit risk of the Former Yugoslav Republic of Macedonia will increase;

- Credit risk will decrease, if the monetary aggregate M2 in the Former Yugoslav Republic of Macedonia will increase;

- If the index of house prices in the Former Yugoslav Republic of Macedonia will grow, then the credit risk would be reduced;

- If the Macedonian exports will grow, then the credit risk should be defused;

- Credit risk will change, if the exchange rate of the dinar to the US dollar and the euro will suffer fluctuations;

- If GDP Macedonian economy will grow, then the credit risk will decrease.

\subsection{Relationship between business credit risk and macroeconomic factors and assumptions}

Loans to businesses constitute a very substantial part of the loans extended. Given this relationship, the dependent variable will be the ratio between non-performing loans to total business loans portfolio compared to (Kalirai \& Scheicher, 2002; Rinaldi \& Sanchis-Arellano, 2006; Kalluci \& Hill, 2010).

\begin{tabular}{|c|c|c|c|c|c|}
\hline Concept & Variable & Symbol & Measure & Position regression & Sign expected \\
\hline Credit risk & Credit with risk & kr_prob_biz & Percent & \multicolumn{2}{|c|}{ Dependent } \\
\hline $\begin{array}{l}\text { no risk interest } \\
\text { rate }\end{array}$ & Rate of bones & bth3 & Percent & Independent & + \\
\hline Aggregate & Aggregate monetary & & & Independent & \\
\hline monetary & $\mathrm{M} 2$ & M2 & Value dinar & & - \\
\hline Export & Growth of export & eks_eur & Log export & Independent & - \\
\hline Exchange rate & $\begin{array}{l}\text { Exchange rate in } \\
\text { dinar me dollar in us } \\
\text { and euro }\end{array}$ & k_këmb & $\begin{array}{l}\text { USD/MAD, } \\
\text { EUR/MAD }\end{array}$ & Independent & $-1+$ \\
\hline \begin{tabular}{|l} 
Economic \\
growth
\end{tabular} & gross domestic product & GDP & Value dinar & Independent & - \\
\hline
\end{tabular}

The rate of loans to businesses depend almost the same factors which depend on macro from the total credit risk, therefore followed the same procedure as to the interpretation of connections. The economic factor has more weight on the dependent variable is thought to be the rate of treasury bills, because the growth rate of the treasury bills, loans are expected to grow business. Regarding the exchange rate it can be said that a devaluation of the domestic currency, is projected to increase business loans. Another factor that affects the quality of business loans is economic growth (GDP), the GDP growth is expected to be accompanied by a reduction in non-performing loans business. Other factors affecting business loan problems are aggregates M2 and exports, both of whom have a negative relationship with the dependent variable, so an increase of these variables are expected to make business credit problems fall. For more reports.

In conclusion, further proposals Kalirai and Scheicher (2002), Rinaldi and Sanchis-Arellano (2006) and Kalluci and Hill (2010), the assumptions for this link are:

- If you increase risk-free interest rate in the Former Yugoslav Republic of Macedonia, the credit risk will increase;

- Credit risk will decrease, if the monetary aggregate M2 in the Former Yugoslav Republic of Macedonia will increase;

- If the Macedonian exports will grow, then the credit risk should be defused;

- Credit risk will change, if the exchange rate of the denar against the euro will undergo fluctuations;

- If GDP Macedonian economy will grow, then the credit risk will decrease

\subsection{The link between non-performing loans to individuals and macroeconomic factors and assumptions}

Following submissions Rinaldi and Sanchis-Arellano (2006) and Kalluci and Hill (2010), loans extended to individuals play an important role in the total loan portfolio. For this reason in this section will discuss the macro-factors affecting the solvency of individuals who are identified below. As dependent variable rate deals arising from the ratio of loans to 
households and total loans extended.

\begin{tabular}{|llcccc|}
\hline Concept & Variable & Symbol & Measure & Position regression Sign expected \\
\hline Credit risk & Credit with risk & kr_prob_biz & Percent & Dependent \\
\hline $\begin{array}{l}\text { Free risk } \\
\text { Aggregate } \\
\text { monetary }\end{array}$ & Rate of bones & Agth3 & Percent & Independent & + \\
\hline Export & Growth of export & eks_eur & Log export & Independent & - \\
\hline Exchange rate & $\begin{array}{l}\text { Exchange rate in dinar } \\
\text { me dollar in us and euro }\end{array}$ & k_këmb & USD/MAD, & Independent & $-/+$ \\
\hline $\begin{array}{l}\text { Economic } \\
\text { growth }\end{array}$ & gross domestic product & GDP & Value dinar & Independent & - \\
\hline
\end{tabular}

Loans to individuals depend on several macro-factors that have a direct effect on them. More specifically, an increase in the rate of treasury bills is expected to increase loans to individuals.

Also, the exchange rate directly affects individuals, and more individuals who loans were taken in foreign currencies and revenues have in local currency, so the value of foreign currency, is projected to increase loans to individuals.

\section{Data}

Secondary data were obtained from several different sources, such as the World Bank, International Monetary Fund, the National Bank of RJM former Office of the Institute of Statistics of former RJM. Best database data has the World Bank, through which it provides information for other countries. Of interest to this dissertation presented data regarding the countries of the region. Through these data become even comparison between countries and former RJM.

Most of the data are in the form of indicators. Among them are given in percentage form, it is inflation or the rate of treasury bills. there are data expressed in money, mainly in money and in euro. Geographic World Bank reports data in local currency and US dollar currency.

The data horizon is 15 years, ie from 2001 onwards. There are some cases when this horizon can not be found, such as foreign direct investment, the recording of which begins in 2005. Also, not all variables are given until 2016, and was a part of variables missing data for 2015.

In academic research in the economic field it is very widespread implementation approach statistical and econometric methods to verify hypotheses or to achieve the objectives. Even when asked to make any prediction, statistical and econometric models used.Using these methods of "wear" reliably academic research because the data and the links between them except that analyzed and tested. Testing of connections between data considered as a mechanism that helps achieve control objectives or hypotheses, and therefore results in general.

Researchers often underestimate the variance process control, trusting mostly intuition and experience. Intuition and experience have their role in the progress of the search, but not enough to say the right reliability results. So overall a serious search should consider the statistical analysis and econometric.

Implementation and use of such methods for the benefit of economic analysis, first of all, requires knowledge of the disciplines of statistics and econometrics. Many cases when researchers underestimate or cursory use these methods. Indeed, there are times when their application is incorrect.

The model is used in this topic $\mathrm{PhD}$ is a multifactorial linear econometric model, which means that to explain a dependent variable considered too independent variables.

Let be given multifactorial linear model,

$$
Y=\beta_{0}+\sum_{i=1}^{p} \beta_{i} X_{i}+\varepsilon
$$

written or otherwise,

$Y=\beta_{0}+\beta_{1} X_{1}+\beta_{2} X_{2}+\ldots+\beta_{p} X_{p}+\varepsilon$

$Y$ is the dependent variable, endogenous, internal, explained, on the left side of the equalizer.

$X i$ are independent variable, exogenous, external explanatory, on the right-hand side, a total of $p$ variables.

$\beta i$ are parameters or coefficients, $\beta 0$ constant is free, while other $\beta$ coefficients are near and independent factors can be recognized as partial regresses;

$\varepsilon$ represents all other factors, whose effects are not taken into consideration. 
Method for assessment of parameters or coefficients of such a model is that of least squares (least square method). She walks with the principle of getting that connection that gives the smallest square distance between the actual observed and model line. With the advancement of technology and software is made possible econometric models evaluated through them easily. Computer programs that researchers often use econometric models to estimate are Microsoft Excel (not very professional), SPSS and EViews.

\subsection{Regression to business credit risk and individuals}

If we refer to the second relationship, rather than $Y$ will have variable business loans (kr_prob_biz). Independent factors that claim to define variable kr_prob_biz are: the rate of loans to businesses of a previous period (kr_prob_bizt-1), the rate of treasury bills quarters (bth3), monetary aggregate M2 (M2) increased exports (eks_eur), exchange rate (k_këmb) and economic growth (GDP). Click regression would change the symbolism of $Y$ and $\bar{X}$ 's, in particular the following variables:

$$
\begin{aligned}
& k r \_p r o b \_b i z_{t}=\beta_{0}+\sum_{i=1}^{p} \beta_{i}\left(\text { variabël_i_pavarur } r_{t}\right)+\varepsilon_{t} \\
& k r \_p r o b \_b i z_{t}=\beta_{0}+\beta_{1} k r_{-} p r o b \_b i z_{t-1}+\beta_{2} b t h 3_{t-1}+\beta_{3} \Delta \log m 2_{t-1} \\
& +\beta_{4} \Delta \log e \text { es_eur }_{t-1}+\beta_{5} \Delta k_{-} k e \ddot{m} b_{t}+\beta_{6} G D P_{-} p_{t-2}+\varepsilon_{t}
\end{aligned}
$$

If we refer to the relationship of the third, then instead of $Y$ will have variable business loans (kr_prob_ind). Independent factors that claim to define variable kr_prob_ind are: the rate of loans to businesses of a previous period (kr_prob_indt-1), the rate of treasury bills quarters (bth3) and bi (bth6), the index of house prices (ind_sh) and exchange rate (k_këmb) with GDP. Click regression would change the symbolism of $Y$ and $X$ 's, in particular the following variables:

$$
\begin{aligned}
& \text { kr_prob_ind } t_{t}=\beta_{0}+\sum_{i=1}^{p} \beta_{i}\left(\text { variabelli_pavarur } r_{t}\right)+\varepsilon_{t} \\
& k r \_p r o b \_ \text {ind } t_{t}=\beta_{0}+\beta_{1} k r_{\perp} \text { prob_ind } d_{r-1}+\beta_{2} b t h 3_{r-1}+\beta_{3} b t h 6_{r-1} \\
& +\beta_{4} \Delta \log i n d_{-} s h_{t-1}+\beta_{5} \Delta \log k_{-} k e \ddot{m} b_{t}+\beta_{6} G D P \_p_{t-1}+\varepsilon_{t}
\end{aligned}
$$

Beta coefficients in the model above or regresses represent partial parameters of the econometric model. The coefficient $\beta 1$ at variable kr_prob_indt- 1 shows that when the rate of loans to households of the previous period increased by one unit, it is expected that non-performing loans to households ( $\left.k r \_p r o b\right)$ increase by $\beta 1$ unit when other factors remain unchanged (ceteris paribus condition). The coefficient at variable bth 3 and bth6 is $\beta 2$ and $\beta 3$, which are interpreted as follows: the growth of one percent rate of treasury bills quarterly (bi), it is expected that the rate of loans to individuals increased by $\beta 2$ ( $\beta 3$, ceteris paribus condition). With $\beta 4$ unit is expected to increase the rate of loans to households, if they increase by a unit housing price index (ceteris paribus condition). If the exchange rate will increase by one unit, then performing loans would increase by $\beta 5$ unit. Also, if the economy performs Macedonian economic growth, it is expected that the rate of non-performing loans to individuals increased by $\beta 6$ unit. $\beta 0$ coefficient indicates the level of problem loans to individuals, when all other factors exert zero impact on the dependent variable.

\section{Conclusion}

In the three cases (total credit risk, business credit risk and households' credit risk) we found positive relationship between previews credit risk to present credit risk, even statistically. This is important for the $99 \%$ confidence level. The total credit risk model shows 4 important variables, with at least 95\% statistical confidence level. According to that, beside the previews level of credit risk, determinants of credit risk are monetary aggregate $\mathrm{M} 2$, exchange rate of the denar against the euro and economic growth. On the other hand, risk free, real estate price index and export growth are not determining factors of it.

Business credit risk model reports 5 important variables, with at least $90 \%$ statistical confidence level. In addition to the previous credit risk, determinants of business credit risk are free risk, monetary aggregate $\mathrm{M} 2$, the exchange rate of the denar against the euro and economic growth. On the other hand, export growth is the only factor that results insignificant.

Households' credit risk model identifies 6 important variables, with at least 90\% statistical confidence level. According to this, beside the previews level of credit risk, determinants of credit risk of individuals are risk-free interest rate, monetary aggregate $\mathrm{M} 2$, the price of houses index, the exchange rate of the denar against the euro and economic growth.

In summary, the three models show the determinants of credit risk in the reality of the Macedonian economy. 


\section{References}

Aggarwall, A. , Watson, S. (1997). Risk Management for Financial Institutions - Advances in Measurement and Control. London: Riskbook, fq.59.

Barisitz, S. (2011). Nonperforming Loans in CESEE - What Do They Comprise? Working paper of Oesterreichische Nationalbank.

Bessis, J. (2010) Risk Management in Banking. Botimi 3.Chichester: John Wiley\&Sons Ltd.

Blaschke, W., Matthew, J., Majnoni, G., \& Peria, S. (2001). Stress testing of financial systems: An overview of Issues, Methodologies, and FSAP experiences. Working paper, International Monetary Fund.

Bozdo, J., \& Kalluci, I. (2006). Credit risk and its management systems. Working paper, Bank of Albania.

Kalirai, H., \& Scheicher, M. (2002). Macroeconomic stress testing: preliminary evidence for Austria. OeNB. Financial Stability, 58-74.

Kalluci, I., \& Kodra, O. (2010). Macroeconomic determinants of credit risk: The case of Albania. Economic policies in SEE: Design, performance and challenges (fv. 73-96). Tirana: Bank of Albania.

Kasekende, L. (2008). Developing a Sound Banking System. Paper presented at IMF.

Keeton, W., \& Morris, C. (1987). Why do banks' loan losses differ? Economic Review, 72(3), 3-21.

Khan, M., \& Senhadji, A. (2000). Financial Development and Economic Growth: An Overview. Working paper, International Monetary Fund.

Mishkin, F. (2007). Housing and the Monetary Transmission Mechanism. Working paper, Federal Reserve. Rinaldi, L., \& SanchisArellano, A. (2006). Household debt sustainability. Working paper, European Central Bank. Skreli, E., \& Çera, G. (2013). Metodologjia e kërkimit në ekonominë e zbatuar. Tiranë: Maluka.

Shijaku, H., \& Ceca, K. (2011). A model for the credit risk in Albania using Banks' panel data. Working paper of Bank of Albania, 6 (29). World Bank (2008). Deposit Insurance around the World: A Comprehensive Database. 